\title{
The protein-sparing effect of $\alpha$-lipoic acid in juvenile grass carp, Ctenopharyngodon idellus: effects on lipolysis, fatty acid $\beta$-oxidation and protein synthesis
}

\author{
Xiao-chen Shi ${ }^{1}$, Ai Jin ${ }^{1}$, Jian Sun ${ }^{1}$, Jing-jing Tian ${ }^{2}$, Hong $\mathrm{Ji}^{1 *}$, Li-qiao Chen ${ }^{3}$ and Zhen-yu Du ${ }^{3}$ \\ ${ }^{1}$ College of Animal Science and Technology, Northwest A\&F University, Yangling 712100, People's Republic of China \\ ${ }^{2}$ Key Laboratory of Tropical and Subtropical Fishery Resource Application and Cultivation, Pearl River Fisheries Research \\ Institute, Chinese Academy of Fishery Sciences, Ministry of Agriculture, Guangzhou 510380, People's Republic of China \\ ${ }^{3}$ School of Life Sciences, East China Normal University, Shanghai 200241, People's Republic of China
}

(Submitted 25 March 2018 - Final revision received 3 July 2018 - Accepted 17 July 2018 - First published online 10 September 2018)

\section{Abstract}

To investigate the protein-sparing effect of $\alpha$-lipoic acid (LA), experimental fish (initial body weight: 18.99 (SD 1.82) g) were fed on a 0 , 600 or $1200 \mathrm{mg} / \mathrm{kg} \alpha$-LA diet for $56 \mathrm{~d}$, and hepatocytes were treated with $20 \mu \mathrm{M}$ compound C, the inhibitor of AMP kinase $\alpha$ (AMPK $\alpha$ ), treated for $30 \mathrm{~min}$ before $\alpha$-LA treatment for $24 \mathrm{~h}$. LA significantly decreased lipid content of the whole body and other tissues $(P<0 \cdot 05)$, and it also promoted protein deposition in vivo $(P<0 \cdot 05)$. Further, dietary LA significantly decreased the TAG content of serum and increased the NEFA content of serum $(P<0.05)$; however, there were no significant differences among all groups in the hepatopancreas and muscle $(P>0 \cdot 05)$. Consistent with results from the experiment in vitro, LA activated phosphorylation of AMPK $\alpha$ and notably increased the protein content of adipose TAG lipase in intraperitoneal fat, hepatopancreas and muscle in vivo $(P<0.05)$. Meanwhile, LA significantly up-regulated the mRNA expression of genes involved in fatty acid $\beta$-oxidation in the same three areas, and LA also obviously down-regulated the mRNA expression of genes involved in amino acid catabolism in muscle $(P<0.05)$. Besides, it was observed that LA significantly activated the mammalian target of rapamycin (mTOR) pathway in muscle of experimental fish $(P<0 \cdot 05)$. LA could promote lipolysis and fatty acid $\beta$-oxidation via increasing energy supply from lipid catabolism, and then, it could economise on the protein from energy production to increase protein deposition in grass carp. Besides, LA might directly promote protein synthesis through activating the mTOR pathway.

Key words: $\alpha$-Lipoic acid: Protein-sparing effect: Lipolysis: Fatty acid $\beta$-oxidation: Ctenopharyngodon idellus

As a result of increasing cost and limited supplies of fish meal, the aquaculture industry has elevated the levels of lipids in the diet, so as to decrease protein utilisation for energy and increase lipid consumption in the aquaculture industry ${ }^{(1)}$. However, prolonged energy imbalance caused by a high-fat diet leads to increased body fat mass and prevalence of the metabolic syndrome in aquatic animals ${ }^{(2)}$. Therefore, it is a high attractive issue in present aquatic nutrition research that an efficient lipid-lowering factor could be found to inhibit lipid accumulation, promote lipid as a key energy source to supply and have the protein-sparing effect.

Recent studies have indicated that $\alpha$-lipoic acid (LA) has potential positive effects on obesity and its related disorders. The research of Kim et al. ${ }^{(3)}$ showed for first time that $\alpha$-LA exerted its anti-obesity effect in rodents by reducing food intake through suppressing hypothalamic AMP kinase $\alpha$ (AMPK $\alpha$ ) activity. However, other studies provided the evidence to reveal the anti-obesity mechanism of $\alpha$-LA that it also could increase energy expenditure by activating phosphorylation of AMPK $\alpha$ in muscle ${ }^{(4)}$. Therefore, there is a dual effect of $\alpha$-LA on AMPK $\alpha$ in different tissues, but the mechanism of AMPK $\alpha$ activation by LA in different situations and parts of the organism has yet to be elucidated. The pivotal anti-obesity mechanism is to promote the breakdown and obliteration of $\mathrm{TAG}^{(5,6)}$. Thus, several studies have suggested that $\alpha$-LA has a positive lipolytic property in animals. Dietary $\alpha$-LA could increase the release of free fatty acids and glycerin in the plasma of chickens ${ }^{(7)}$. Lipolysis, as a complicated process, involves several lipases and lipid droplet proteins in various tissues, including adipose TAG lipase (ATGL) and hormone-sensitive lipase $(\mathrm{HSL})^{(8,9)}$. Further studies indicate that the mechanism of lowering effect on $\alpha$-LA is to increase ATGL protein content via activating phosphorylation of AMPK $\alpha$ in HepG2 cells ${ }^{(10)}$. However, recent studies

Abbreviations: 4E-BP, 4E binding protein; AMPK $\alpha$, AMP kinase $\alpha$; ATGL, adipose TAG lipase; CPT- $1 \alpha$, carnitine palmitoyltransferase-1 $\alpha$; IPF, intraperitoneal fat; LA, lipoic acid; mTOR, mammalian target of rapamycin; PA, palmitic acid.

* Corresponding author: Professor H. Ji, fax +86029 87092585, email jihong@nwsuaf.edu.cn 
demonstrated that increasing lipolysis and free fatty acid release induced by $\alpha$-LA from adipocyte tissue do not have significant effect on insulin resistance in mammals ${ }^{(5)}$. Therefore, $\alpha$-LA might have the ability to utilise fatty acids that are released from TAG via $\beta$-oxidation. Furthermore, the improvement of lipid consumption, like fatty acid $\beta$-oxidation, has a protein-sparing effect via decreasing protein utilisation for energy in fish ${ }^{(1)}$. However, it is yet to be clarified whether $\alpha$-LA has proteinsparing effects via regulation of lipid metabolism in fish.

The previous study indicated that $\alpha$-LA could activate phosphorylation of mammalian target of rapamycin (mTOR) pathway in brain endothelial cells to promote protein synthesis ${ }^{(11)}$. Besides, $\alpha$-LA could promote glomerular mesangial cell growth and secretion of matrix proteins via activating the mTOR pathway under high-glucose conditions ${ }^{(12)}$. However, there is no evidence currently suggesting that $\alpha$-LA promotes protein deposition and synthesis in vivo.

Grass carp (Ctenopharyngodon idellus) is one of the economically important herbivorous freshwater fish farmed in China ${ }^{(13)}$ and easily accumulates excessive fat in the abdominal cavity and suffers from fatty liver in aquaculture ${ }^{(14)}$. So grass carp has been regarded as quite a good model for lipid metabolism study in fish.

Above all, in the present study, we aimed to investigate whether $\alpha$-LA, as an efficient nutrient factor, has a proteinsparing effect via promoting lipid catabolism, increasing the energy supply from lipid sources and sparing protein from energy production to increase protein deposition in grass carp.

\section{Methods}

\section{Experimental diets}

The formulation and proximate composition of the experimental diets are shown in online Supplementary Table S1. In all, three isonitrogenous (33.0\% crude protein) and isolipidic (5.0\% crude lipid) experimental diets were supplemented with $\alpha$-LA at different concentrations of 0 (control, without extra $\alpha$-LA addition), $600 \mathrm{mg} / \mathrm{kg}$ (LA1) and $1200 \mathrm{mg} / \mathrm{kg}$ (LA2) diet. The dietary level of LA in the present study is based on the results of study by Kütter et al. ${ }^{(15)}$ in Trachinotus marginatus. This study has reported that high reduction in specific growth rate at high doses (1750 and $3000 \mathrm{mg} / \mathrm{kg}$ ) and diets supplemented with 500 and $1000 \mathrm{mg} / \mathrm{kg}$ exhibited the positive effects of LA, such as lower thiobarbituric acid-reactive substances in muscle and higher glutathione S-transferase activity in brain compared with the control group $^{(15,16)} \cdot \alpha$-LA (>99\% purity) was obtained from Suzhou Fushilai Pharmaceutical Co. Ltd. All ingredients were purchased from Hua-qin Husbandry and Technology Co. Ltd. Fish meal, soyabean meal, cottonseed meal and other ingredients were used as dietary protein sources. Soyabean oil (Kerry Oils \& Grains Co. Ltd), lard oil (Kangle Market) and linseed oil (Hoval Seasons Bio-Sci Co. Ltd) were added to satisfy the essential fatty acid requirements (1.0\% linoleic acid and $1.0 \% \alpha$-linolenic acid) of grass carp ${ }^{(17)}$. The dough was pelleted to proper size $(2.5 \mathrm{~mm}$ pellet diameter $)$ and the pellets were dried in a cool and well-ventilated room for about $12 \mathrm{~h}$ and then kept in a freezer at $-20^{\circ} \mathrm{C}$ until use.

\section{Experimental procedure}

The experimental procedures were similar to those described in our previous study ${ }^{(18)}$. After fasting for $24 \mathrm{~h}, 162$ fish (initial body weight: 18.99 (SD 1.82) g) were randomly distributed into nine 225-litre tanks (diameter $=0.75 \mathrm{~m}$, height $=0.7 \mathrm{~m}$ ) in a recirculation system. Each diet was distributed randomly to triplicate aquariums. The fish were hand-fed the experimental diets three times daily (at 08.30, 12.30 and 16.30 hours, respectively) to apparent satiation for 8 weeks. The feed intake was recorded. Each tank was supplied with a heating rod for maintaining the water temperature at $28^{\circ} \mathrm{C}$ and the photoperiod was $12 \mathrm{~h}$ light $-12 \mathrm{~h}$ dark. During the feeding experiment, water was circularly filtered and renewed by $1 / 5$ daily to maintain acceptable water quality. The dissolved $\mathrm{O}_{2}, \mathrm{pH}$ and ammonia content maintained at $15.03(\mathrm{sD} 0 \cdot 17), 7 \cdot 32$ (SD 0.08) and $0 \cdot 10$ (SD 0.04) $\mathrm{mg} / \mathrm{l}$, respectively. Dead fish were weighed and recorded for calculating the mortalities.

\section{Sampling procedure and calculations}

The procedures were approved by the Animal Care and Use Committee of Northwest A\&F University and performed in accordance with animal welfare and ethics. After 8 weeks of feeding, the fish were fasted for $24 \mathrm{~h}$. All fish were anaesthetised with tricaine methane sulfonate (MS-222; 0.06 g/l; Sigma-Aldrich). Fish were weighed and their body length was measured. In all, two fish per aquarium were kept at $-20^{\circ} \mathrm{C}$ for whole body proximate composition analysis. In all, six fish per aquarium were randomly selected for blood collection from the caudal vein, and sampled blood was allowed to clot at $4^{\circ} \mathrm{C}$ for $6 \mathrm{~h}$. The serum of six fish was collected after centrifugation of the clot for $10 \mathrm{~min}(825 \mathrm{~g}$, $4^{\circ} \mathrm{C}$ ), which were pooled as three samples per aquarium, frozen in liquid $\mathrm{N}_{2}$ and stored at $-80^{\circ} \mathrm{C}$ until analysis. The muscle and hepatopancreas that were excised from the six fish per aquarium were stored at $-20^{\circ} \mathrm{C}$ for proximate composition analysis. The remaining fish were killed and dissected. After weighing the total visceral weight, the hepatopancreas, intraperitoneal fat (IPF), kidney, spleen and intestine were stripped and weighed. Afterwards, samples of the hepatopancreas, muscle and IPF from three fish per aquarium were frozen in liquid $\mathrm{N}_{2}$ and then stored at $-80^{\circ} \mathrm{C}$ for gene expression and Western blot analysis, respectively, and hepatopancreas and IPF from the other four fish per aquarium were fixed in paraformaldehyde solution for histology analysis.

The following formulae were used to calculate growth performance and biological parameters:

$$
\begin{aligned}
& \text { Specific growth rate }(\% / \mathrm{d})=(\text { Ln final weight }(\mathrm{g})-\text { Ln initial } \\
& \text { weight }(\mathrm{g})) \times 100 / \mathrm{d}
\end{aligned}
$$

Feed conversion ratio $=$ amount of feed given $(\mathrm{g})$

$$
\text { / weight gain }(\mathrm{g})
$$


Protein efficiency ratio $($ PER, \% $)=$ weight gain $\times 100$ / total protein intake

Protein productive value (PPV, \%)

$=$ total protein gain $\times 100 /$ total protein intake

Viscerosomatic index (VSI, \%)

= viscerosomatic weight $(\mathrm{g}) \times 100 /$ body weight $(\mathrm{g})$

Kidney index $(\mathrm{KI}, \%)=$ kidney weight $(\mathrm{g}) \times 100 /$ body weight $(\mathrm{g})$

Hepatopancreas index (\%)

$=$ hepatopancreas weight $(\mathrm{g}) \times 100 /$ body weight $(\mathrm{g})$

Spleen index $($ SI, \% $)=$ spleen weight $(\mathrm{g}) \times 100 /$ body weight $(\mathrm{g})$

$\mathrm{IPF}$ index $(\%)=\mathrm{IPF}$ weight $(\mathrm{g}) \times 100 /$ body weight $(\mathrm{g})$

Relative intestine length (RIL, \%)

$=$ intestinal length $(\mathrm{cm}) \times 100 /$ body length $(\mathrm{cm})$

\section{Cell culture and treatment}

The hepatocytes (L8824) of grass carp were bought from the China Centre for Type Culture Collection (CCTCC). The hepatocytes were placed into M199 cell culture medium (Thermo Scientific) with $10 \%$ fetal bovine serum and incubated at $28^{\circ} \mathrm{C}$ in a $5 \% \mathrm{CO}_{2}$ humidified atmosphere, and the medium was refreshed every 2 or $3 \mathrm{~d}$ until cell confluence. For experiment, the confluent hepatocytes were then placed into M199 cell culture medium with $250 \mu \mathrm{m}$ palmitic acid (PA) (P5585; SigmaAldrich Inc.) and cultivated at $28^{\circ} \mathrm{C}$ in a $5 \% \mathrm{CO}_{2}$ humidified atmosphere for $24 \mathrm{~h}$. Then, the cells were treated with $\alpha$-LA (T1395; Sigma-Aldrich Inc.) for $24 \mathrm{~h}$. About $20 \mu \mathrm{m}$ compound C (HY-13418; Medchem Express Inc.) in water, the inhibitor of phosphorylation of $\mathrm{AMPK} \alpha$, was added $30 \mathrm{~min}$ before the addition of $\alpha$-LA.

\section{Proximate composition analysis}

The proximate composition of the diets, hepatopancreas, muscle and whole body were determined according to the methods of the Association of Official Analytical Chemists Procedures $(1995)^{(19)}$. Briefly, the samples were dried to a constant weight to determine moisture at $105^{\circ} \mathrm{C}$. Crude protein was determined by measuring $\mathrm{N}(\mathrm{N} \times 6 \cdot 25)$ of the samples using the Kjeldahl method. Crude lipid was measured by diethyl ether extraction using the Soxhlet method.

\section{TAG measurement}

The TAG measurement was performed based on the standard method, as previously described ${ }^{(20)}$. After the treatment, cells in each well were collected for the measurement of glycerol concentration using a Triglyceride Determination Kit (Jiancheng Biotechnology Co.) according to the manufacturer's protocol. The kit utilises a spectrophotometric method with glycerol-3- phosphate oxidase and phenol aminophenazone. The increase in absorbance at $510 \mathrm{~nm}$ is directly proportional to the TAG concentration of the sample.

NEFA and enzyme activity of alanine aminotransferase and aspartate aminotransferase measurement

The NEFA and enzyme activity of ALT and AST from serum, hepatopancreas and muscle were measured by using an assay kit (Jiancheng Biotechnology Co.). The content of NEFA and enzyme activity of ALT and AST were measured based on the user's manual step by step.

\section{Histological processing and morphological evaluation}

The samples of fixed hepatopancreas and IPF were washed in tap water for $12 \mathrm{~h}$, followed by a routine dehydration in a graded series of ethanol (30, 50, 70, 80, 90, 95 and $100 \%$ twice). The samples were then equilibrated in xylene and embedded in paraffin based on the standard histological techniques as described previously ${ }^{(21,22)}$. Afterwards, sections were cut at $5 \mu \mathrm{m}$ with the use of a rotary microtome (RM2235; Leica) and mounted in glass slides, which were then stained with haematoxylin and eosin. Histological samples were observed and photographed by using an upright microscopy (Leica Biosystems). The average adipocyte size per image was quantified using Photoshop (Adobe), as previously described ${ }^{(23)}$. An average value across five nonoverlapping images (five/section) was calculated for each group.

\section{Oil Red O staining}

Oil red $O$ staining was performed based on the standard method, as previously described ${ }^{(24)}$. The dye was extracted with isopropanol. The optical density (OD) was estimated at an absorbance of $490 \mathrm{~nm}$ using a microtitre plate spectrophotometer (Multiskan MK3; Thermo Labsystems). The cellular lipid content was calculated from the OD value.

\section{Real-time quantitative RT-PCR}

RNA extraction, complementary DNA synthesis and gene expression measurements of tissues and cell samples in experiments were performed as described previously ${ }^{(18,25)}$. The primer sequences for $\beta$-actin, ATGL, HSL, fork-head box O1 (FOXO1), PPAR , lipoprotein lipase ( $L P L)$, fatty acid synthase $(F A S)$, diacylglycerol $O$-acyltransferase (DGAT), $P P A R \gamma$, carnitine palmitoyltransferase- $1 \alpha(C P T-1 \alpha)$, target of rapamycin $(T O R)$, insulin-like growth factor-1, ribosomal protein 56 kinase $(S 6 K)$, glutamate dehydrogenase $(G L D H)$, myogenic differentiation antigen $(M y O D)$ and myogenin $(M y o G)$ are listed in online Supplementary Table S2. After the PCR, melting curves were analysed to confirm that single products were obtained in these reactions. A relative quantification method, the comparative $C_{\mathrm{t}}$ method $\left(2^{-\Delta \Delta C_{\mathrm{t}}}\right)$, was used to calculate the gene expression values, as described in the literature ${ }^{(26,27)}$. 


\section{Western blotting analysis}

Tissues were homogenised with glass Tenbroeck tissue grinders (Kimble Chase) on ice and lysed with lysis buffer (Beyotime Technologies Inc.) containing protease and phosphatase inhibitor cocktails (Roche) at $4^{\circ} \mathrm{C}$ for $1 \mathrm{~h}$ and cleared by centrifugation at $13000 \mathrm{~g}$ for $10 \mathrm{~min}$ at $4^{\circ} \mathrm{C}$. Cultured cells were lysed in lysis buffer containing protease and phosphatase inhibitor cocktails on ice. Crude lysates were centrifuged at $13000 \mathrm{~g}$ for $10 \mathrm{~min}$ at $4^{\circ} \mathrm{C}$. Total protein concentration from the resultant supernatant was determined by a bicinchoninic acid protein assay kit (Biobox, Biotech. Co. Ltd). Protein samples were separated by SDS-PAGE and transferred to a polyvinylidene difluoride membrane (Beyotime Technologies Inc.) by electroblotting. Membranes were incubated overnight at $4^{\circ} \mathrm{C}$ with primary antibodies. After washing, the secondary antibody was added and incubated for $2 \mathrm{~h}$ at room temperature and protein bands were visualised by ECL Plus (ZETA). The membranes were then stripped and reprobed with anti- $\beta$-actin antibody. Densitometric quantitation was performed using a Sagecreation imaging system with Sagecreation Quantity One software (Sagecreation Co. Ltd). The following antibodies (Cell Signaling Technology) were used: antibodies against AMPK $\alpha$ (2532), phosphor-AMPK $\alpha$ (Thr172, 2531), protein kinase B (Akt, 9272), phosphor-Akt (Ser473, 9271), TOR (2972), phosphorTOR (Ser2448, 2971), p70S6K (9202), phosphor-p70S6K (Ser389, 9234), eukaryotic initiation factor 4E binding protein (4E-BP)-1 and phosphor-4E-BP1 (Thr37/46, 9459). All these antibodies were developed using antigenic regions completely conserved in fish, and many had been successfully used in fish and published before ${ }^{(28)}$.

\section{Statistical analysis}

The values of biological parameters (replicates of sixteen samples per aquarium) and proximate composition of tissues (replicates of six samples per aquarium) are means and standard deviations, $n$ 3. The values of whole body proximate composition analysis (replicates of six samples per group) are means and standard deviations, $n 6$. And the values of others are means and standard deviations, $n 9$ (replicates of nine samples per group). Percentage data were arcsine-transformed before analysis. One-way ANOVA was used to compare differences among the experimental groups, followed by Duncan's post hoc tests. All analyses were conducted using PASW Statistics 18 (SPSS). A significance level of $P<0.05$ was used for all tests.

\section{Results \\ Dietary $\alpha$-lipoic acid inhibits lipid accumulation and promotes protein deposition in grass carp in vivo}

No significant differences in the final body weight, specific growth rate, feed conversion ratio, survival rate and other parameters, including VSI, KI, SI and RIL, were observed in all treatment groups $(P>0.05)$ (Table 1$)$. However, the lipid content of the whole body was significantly decreased in those fish fed on the diet with $\alpha$-LA at the doses of 600 and $1200 \mathrm{mg} / \mathrm{kg}$, compared with the control group $(P<0 \cdot 05)$ (Table 1$)$. The fish fed on the $\alpha$-LA diet showed a remarkable decrease in adipocyte size and IPF index $(P<0.05)$ (Fig. 1(J) and (K)). Meanwhile, the TAG content of serum in the treatment at the dose of $1200 \mathrm{mg} \mathrm{LA} / \mathrm{kg}$ was significantly lower than that of the control group and the dietary $\alpha$-LA $600 \mathrm{mg} / \mathrm{kg}$ group $(P<0 \cdot 05)$ (Fig. 1 (A)), and NEFA content of serum in the control group was remarkably higher than the content in the LA groups $(P<0.05)$ (Fig. 1(B)). In addition, the crude lipid content of the hepatopancreas and muscle showed a significant decrease in fish fed on the $\alpha$-LA diet $(P<0.05)$ (Fig. 1(E) and 1(G)), with the lipid content of the hepatopancreas of fish in LA groups being observably lower than that in the control group $(P<0.05)$ (Fig. 1(E)). However, NEFA content of the hepatopancreas and muscle was not significant among all groups $(P>0.05)$ (Fig. 1(F) and $(\mathrm{H})$ ). The ALT and AST enzyme activity showed a significant decrease in LA groups $(P<0.05)$ (Fig. 1(C) and (D)), although the morphological analysis of the hepatopancreas exhibited no marked change among all groups (Fig. 1(I)).

Interestingly, the crude protein content of the whole body and muscle showed a significant increase in the fish fed on the $\alpha$-LA

Table 1. Effects of dietary a-lipoic acid (LA) on the biological parameters and whole-body chemical analysis of grass carp (Mean values and standard deviations, $n 3$ per group)

\begin{tabular}{|c|c|c|c|c|c|c|}
\hline & \multicolumn{2}{|c|}{ Control } & \multicolumn{2}{|c|}{ LA1 } & \multicolumn{2}{|c|}{ LA2 } \\
\hline & Mean & SD & Mean & SD & Mean & SD \\
\hline Initial weight (g) & 18.96 & 0.02 & 18.97 & 0.04 & 18.99 & 0.02 \\
\hline Final weight $(\mathrm{g})$ & 76.65 & 1.48 & 74.85 & 1.67 & 74.36 & 1.27 \\
\hline Special growth rate $(\% / d)$ & 2.34 & 0.18 & 2.45 & 0.04 & $2 \cdot 32$ & 0.17 \\
\hline Feed conversion ratio & 1.40 & 0.07 & 1.41 & 0.03 & 1.40 & 0.03 \\
\hline Kidney index (\%) & 0.35 & 0.04 & 0.34 & 0.02 & 0.37 & 0.02 \\
\hline Spleen index (\%) & 0.29 & 0.01 & 0.24 & 0.01 & 0.23 & 0.02 \\
\hline Relative intestine length (\%) & 1.36 & 0.22 & $1 \cdot 15$ & 0.11 & $1 \cdot 14$ & 0.11 \\
\hline Viscera index (\%) & $15 \cdot 51$ & 1.84 & $15 \cdot 45$ & 1.07 & 14.56 & 1.37 \\
\hline Survival rate (\%) & 100 & 0.00 & 100 & 0.00 & 100 & 0.00 \\
\hline Lipid content of whole body* (\%) & $8 \cdot 27^{\mathrm{a}}$ & $1 \cdot 27$ & $6 \cdot 76^{\mathrm{b}}$ & 0.93 & $6 \cdot 19^{\mathrm{b}}$ & 1.18 \\
\hline Protein content of whole body (\%) & $12 \cdot 46^{\mathrm{b}}$ & 0.72 & $14.50^{\mathrm{a}}$ & 1.56 & $13 \cdot 28^{a, b}$ & 0.49 \\
\hline
\end{tabular}

a,b Mean values with unlike superscript letters were significantly different $(P<0.05)$.

${ }^{*}$ Calculated as percentage of wet weight. 
diet at doses of 600 and $1200 \mathrm{mg} / \mathrm{kg}$ compared with the control group except for which in the hepatopancreas $(P<0.05)$ (Fig. 1(L)). The protein efficiency ratio and protein productive value, which reflect the status of protein deposition in the body, were significantly increased in fish fed on the $\alpha$-LA diet at the dose of $1200 \mathrm{mg} / \mathrm{kg}$, compared with the control group and fish fed $\alpha$-LA at the dose of $600 \mathrm{mg} / \mathrm{kg}(P<0 \cdot 05)$ (Fig. 1(M)).

\section{Effect of dietary $\alpha$-lipoic acid on protein expression and mRNA expression levels of genes involved in lipid metabolism in grass carp in vivo}

To expound the mechanism of $\alpha$-LA inhibits lipid accumulation in grass carp, the protein expression and mRNA expression levels of genes involved in lipid metabolism in the hepatopancreas, muscle and IPF were detected, and the results were shown in Fig. 2 and online Supplementary Fig. S1. Results indicated that the mRNA expression of $A T G L$ was significantly up-regulated in IPF, hepatopancreas and muscle of the fish fed with dietary $\alpha$-LA at doses of 600 and $1200 \mathrm{mg} / \mathrm{kg}(P<0.05)$ (Fig. 2(D)-(F)). Dietary $\alpha$-LA at doses of 600 and $1200 \mathrm{mg} / \mathrm{kg}$ significantly up-regulated the mRNA expression of $L P L$ in the hepatopancreas and muscle $(P<0.05)$ (Fig. 2(E) and (F)). As shown in Fig. 2(D)-(F), dietary $\alpha$-LA at doses of 600 and $1200 \mathrm{mg} / \mathrm{kg}$ could significantly increase the PPAR $\alpha \mathrm{mRNA}$ expression level in the IPF and muscle except for the hepatopancreas. However, the mRNA expression of $C P T-1 \alpha$ was markedly up-regulated in muscle and hepatopancreas in the treatment at doses of 600 and $1200 \mathrm{mg} \mathrm{LA} / \mathrm{kg}(P<0.05)$, but not in the IPF $(P>0.05)$ (Fig. 2(D)-(F)). In addition, mRNA expression levels of other genes involved in lipolysis, fatty acid de novo synthesis and re-esterification showed no significant differences among all groups, including HSL, FOXO1, FAS and DGAT1 $(P>0.05)$ (online Supplementary Fig. S1). Similar to mRNA expression results, dietary $\alpha$-LA significantly increased the ATGL protein expression in muscle, hepatopancreas and IPF. However, $\alpha$-LA supplementation at doses of 600 and $1200 \mathrm{mg} / \mathrm{kg}$ significantly decreased PPAR $\gamma$ protein expression in IPF $(P<0.05)$ (Fig. 2(A)-(C)). Interestingly, the phosphorylation level of AMPK $\alpha$ was significantly increased in the IPF, hepatopancreas and muscle of the fish fed on the $\alpha$-LA diet at doses of 600 and $1200 \mathrm{mg} / \mathrm{kg}(P<0.05)$ (Fig. 2(A)-(C)).

\section{$\alpha$-Lipoic acid promotes lipolysis via modulating AMP kinase pathway in grass carp in vivo}

To explore the mechanism of lipolysis regulated by $\alpha$-LA, we examined the effect of $\alpha$-LA in cell culture. The hepatocytes of grass carp were treated with a series of LA concentrations $(0,50$, 250, 500 and $1000 \mu \mathrm{M}$ ) for $24 \mathrm{~h}$. Quantification using oil red $\mathrm{O}$ staining was conducted and TAG content was measured, and the results were shown in Fig. 3(A) and (B). Results indicated that $\alpha$-LA significantly decreased the TAG content in a dosedependent manner $(P<0 \cdot 05)$.

To evaluate the ability of $\alpha$-LA to modify the AMPK pathway involved in the regulation of lipolysis, the PA treatment hepatocytes were treated with compound $\mathrm{C}$ for $30 \mathrm{~min}$, before the addition of $\alpha$-LA $(250 \mu \mathrm{m}, 24 \mathrm{~h})$. As shown in Fig. 3, the TAG content was significantly increased following PA treatment, compared with the control group $(P<0.05)$ (Fig. 3(C)). However, $\alpha$-LA markedly inhibited the increase induced by PA, and compound C dramatically inhibited the ability of $\alpha$-LA $(P<0.05)$ (Fig. 3(C)). $\alpha$-LA significantly increased the levels of phosphorylation of AMPK and protein expression of ATGL compared with PA treatment, and compound C remarkably prevented the increase induced by $\alpha$-LA $(P<0.05)$ (Fig. 3(E)). The mRNA expression levels of ATGL, PPAR $\alpha$ and $C P T-1 \alpha$ were notably increased after $\alpha$-LA treatment; however, compound C significantly inhibited the mRNA expression of genes involved in lipolysis and fatty acid $\beta$-oxidation $(P<0.05)$ (Fig. 3(D)).

\section{Effect of dietary $\alpha$-lipoic acid on protein expression and $m R N A$ expression levels of genes involved in protein synthesis in grass carp in vivo}

To explore the potential mechanism underlying the ability of $\alpha$-LA to promote protein synthesis and deposition in grass carp in vivo, the protein and mRNA expression levels of genes involved in protein metabolism of muscle and hepatopancreas were detected, and the results were shown in Fig. 4. Compared with the control group, no significant differences in the phosphorylation levels of mTOR, AKT and S6K were detected in the hepatopancreas among all groups $(P>0.05)$, except for the phosphorylation level of $4 \mathrm{E}-\mathrm{BP}$ in the fish fed on the $\alpha$-LA diet $(P<0.05)$ (Fig. 4(A)). Interestingly, LA supplementation at the dose of $1200 \mathrm{mg} / \mathrm{kg}$ exhibited the highest phosphorylation levels of mTOR, AKT, S6K and 4E-BP in the muscle of fish $(P<0.05)$ (Fig. 4(B)). Meanwhile, the mRNA expression level of $m T O R$ was markedly up-regulated by $\alpha$-LA at the dose of $1200 \mathrm{mg} / \mathrm{kg}$ compared with the control group and dietary $\alpha$-LA $600 \mathrm{mg} / \mathrm{kg}$ group (Fig. 4(C)). Conversely, mRNA expression of $G L D H$ was obviously down-regulated by $\alpha$-LA compared with the control group $(P<0.05)$ (Fig. $4(\mathrm{C})$ ). However, the gene expression of $M y O D$ and $M y o G$ was not significantly different in fish fed on the $\alpha$-LA diet from those of the control group $(P>0.05)$ (Fig. 4(D)).

\section{Discussion}

Since protein sources are the most expensive components in aquafeed, from an economic standpoint, protein-sparing by use of non-protein energy sources is gaining more attention from the aquaculture industry; it is believed that this can be achieved by increasing dietary lipid levels. However, increased lipid levels in the diet cause excess lipid accumulation and a higher prevalence of metabolism disorders in aquaculture practice ${ }^{(29-31)}$. Grass carp, a herbivorous freshwater fish, is a good example, which fed high-energy feed easily and exhibit extensive body fat deposits, especially in viscera and liver during the cultivation ${ }^{(32)}$. Therefore, it is highly attractive to identify an efficient lipid-lowering factor to inhibit lipid accumulation and promote protein deposition in aquatic nutrition. $\alpha$-LA is widely accepted that it possesses antioxidant properties in mammals and aquatic organisms ${ }^{(16,33)}$. The present study 
(A)

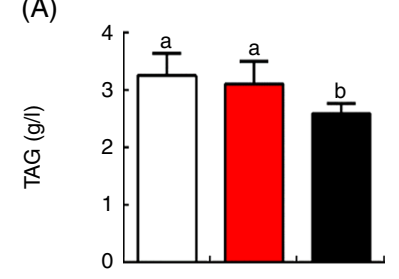

(B)

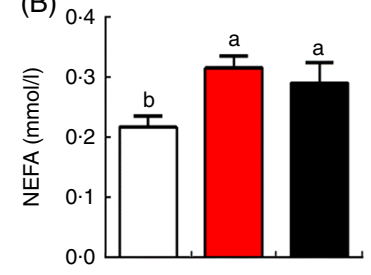

(E)

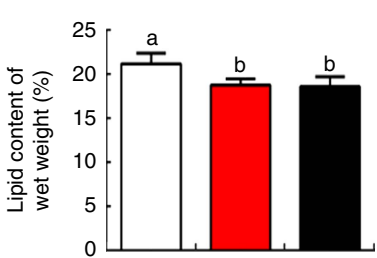

(F)

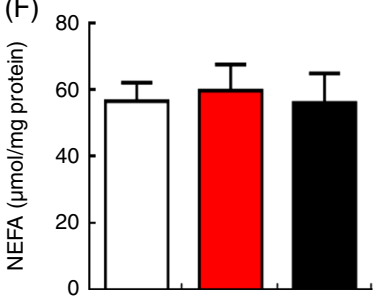

Hepatopancreas
(C)

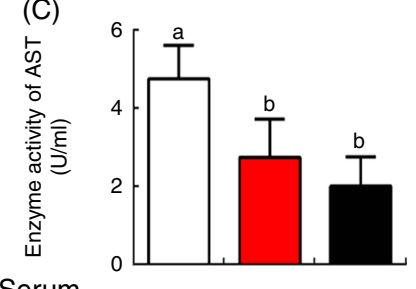

Serum

(G)

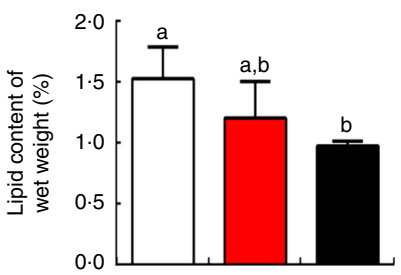

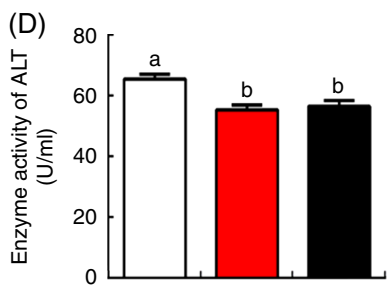

$(\mathrm{H})$

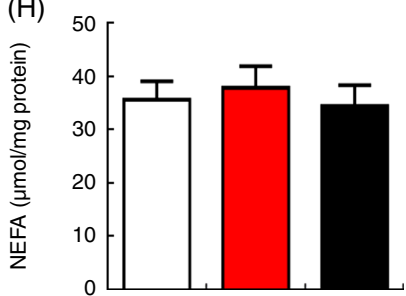

Muscle (l)

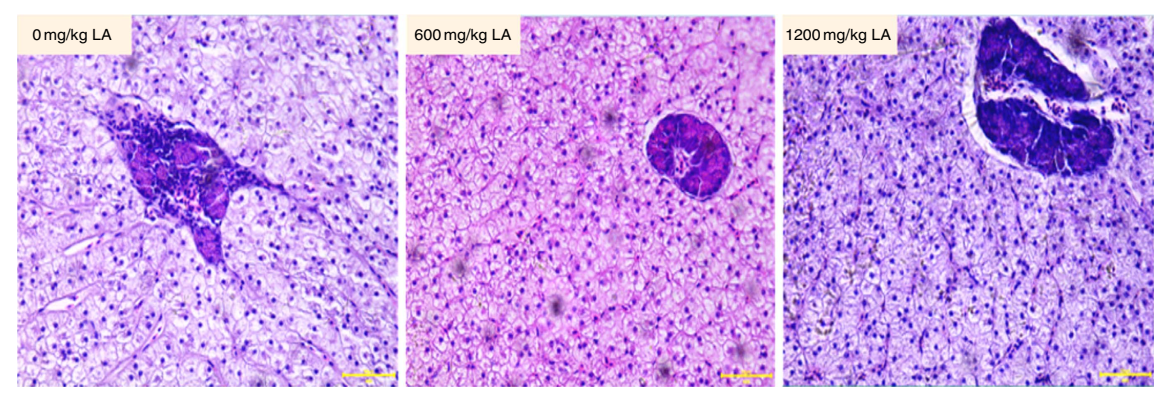

(K)

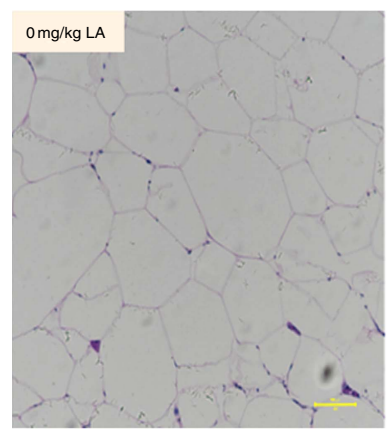

(L)
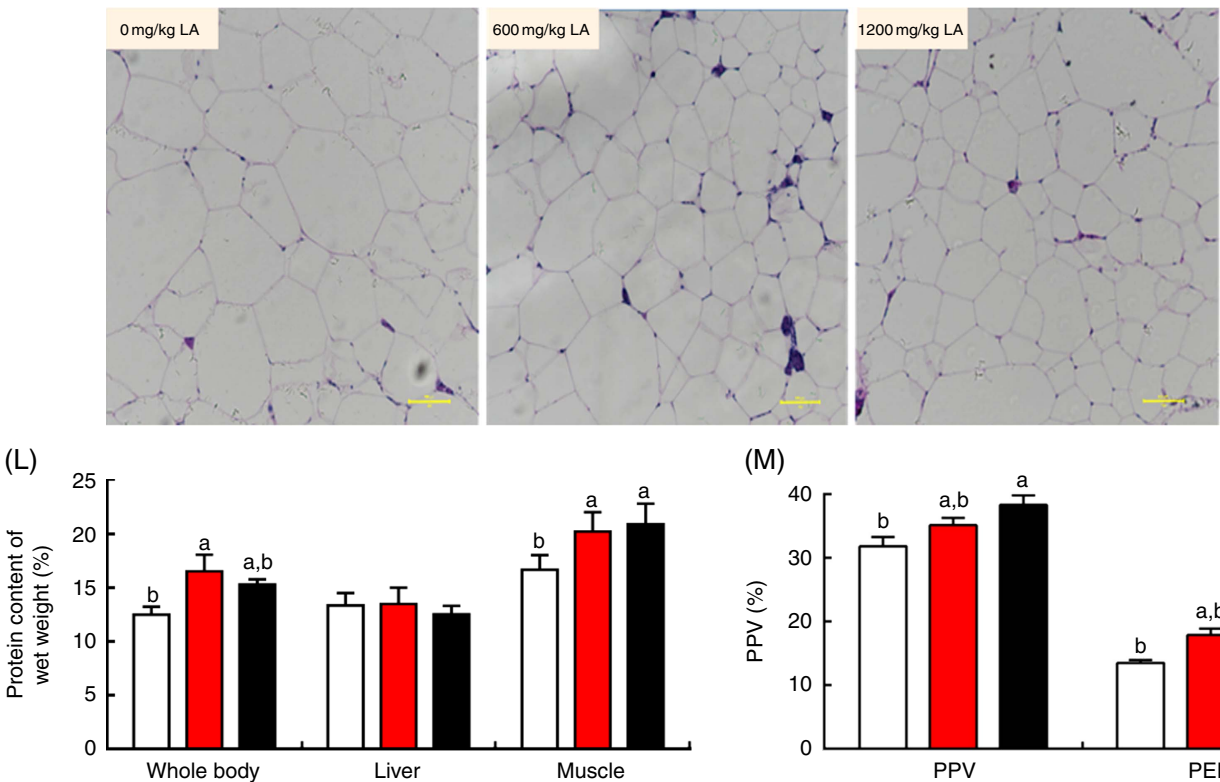

(M)
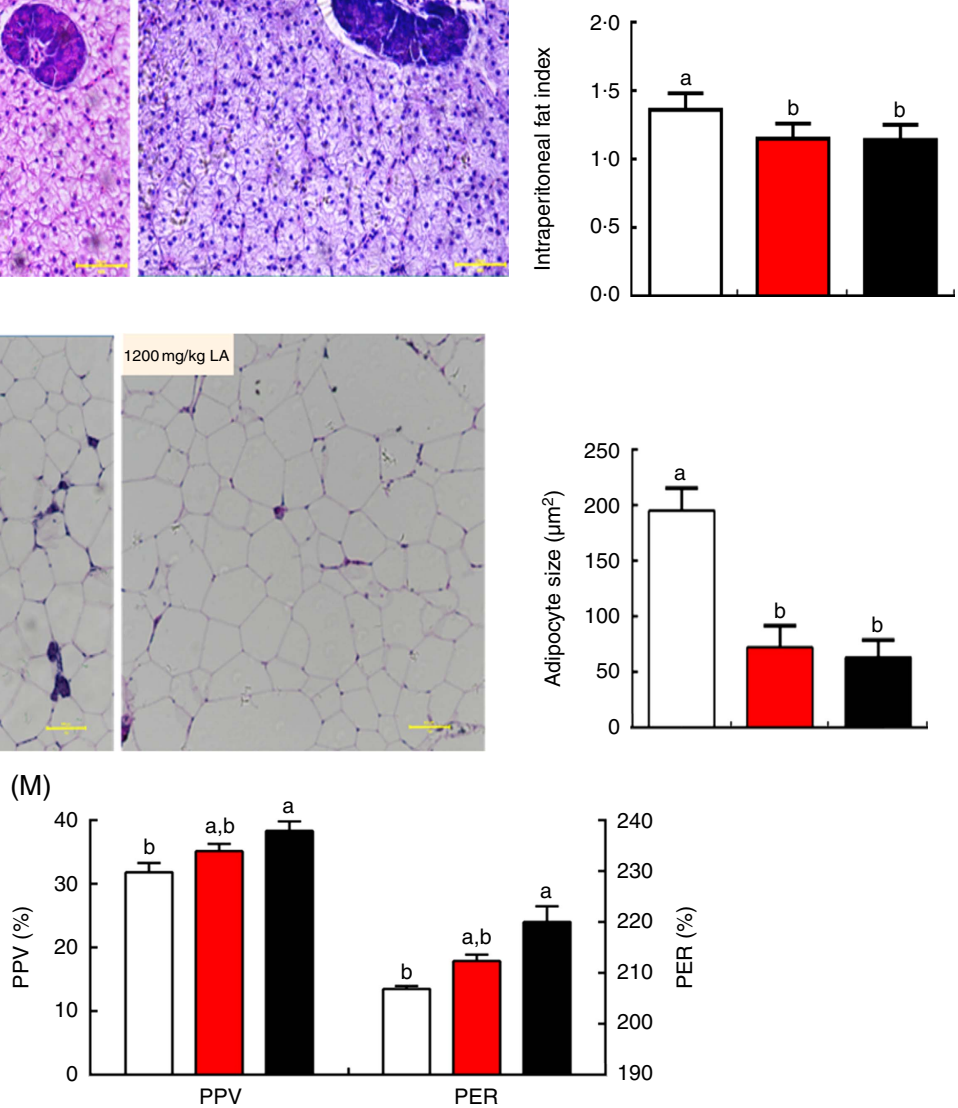

Fig. 1. Dietary $a$-lipoic acid (LA) inhibits lipid accumulation and promotes protein deposition in grass carp in vivo. (A) TAG content of serum in experimental fish; (B) NEFA content of serum in experimental fish; (C and D) enzyme activities of aspartate aminotransferase (AST) and alanine aminotransferase (ALT) in serum; (E and F) lipid and NEFA content of the hepatopancreas in experimental fish; (G and H) lipid and NEFA content of muscle in experimental fish; (I) morphology of the hepatopancreas in experimental fish (haematoxylin and eosin staining, original magnification 200x); (J) intraperitoneal fat index; (K) morphology of intraperitoneal fat (haematoxylin and eosin staining, original magnification 200x) and adipocyte size in experimental fish; (L) crude protein content of the whole body, hepatopancreas and muscle in experimental fish; (M) protein efficiency ratio (PER) and protein productive value (PPV) of experimental fish. The values of biological parameters (replicates of sixteen samples per aquarium) and proximate composition of tissues (replicates of six samples per aquarium) are means, with standard deviations represented by vertical bars, $n 3$. The values of whole body proximate composition analysis (replicates of six samples per group) are means, with standard deviations represented by vertical bars, $n 6$. Other values are means, with standard deviations represented by vertical bars, $n 9$ (replicates of nine samples per group). ${ }^{a, b}$ Mean values with unlike letters were significantly different between groups, $P<0.05$ (one-factor ANOVA, Duncan's post hoc test). $\square, 0 \mathrm{mg} / \mathrm{kg}$ LA; $\square, 600 \mathrm{mg} / \mathrm{kg}$ LA; $\square$, $1200 \mathrm{mg} / \mathrm{kg} \mathrm{LA}$. 
(A)

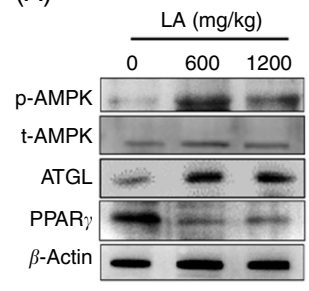

(B)
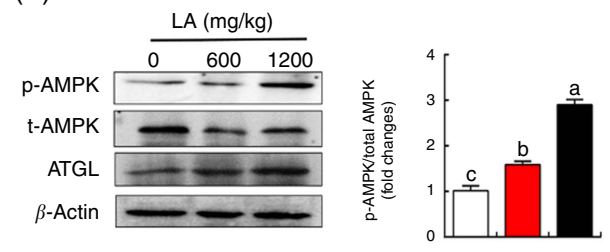

(C)

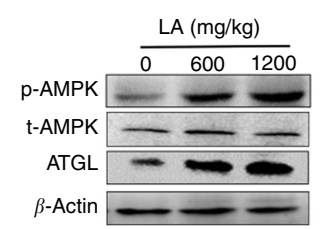

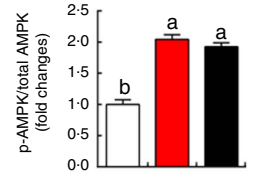
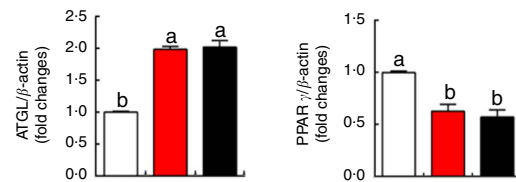

Intraperitoneal fat
(D)

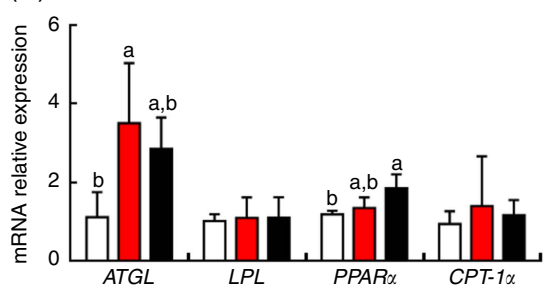

(E)

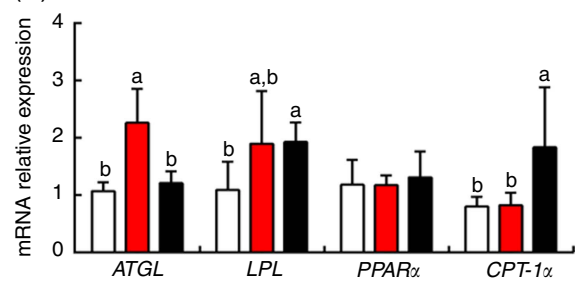

(F)

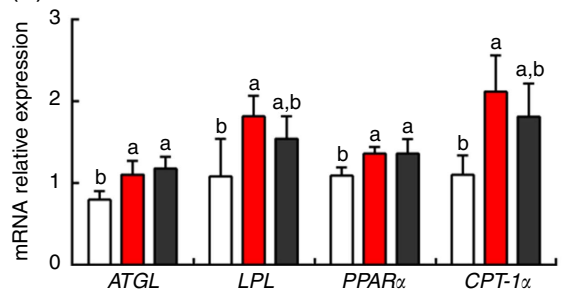

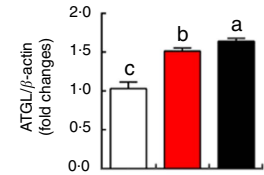

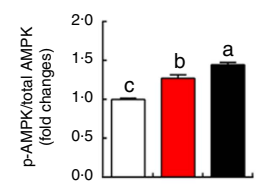

\section{Muscle}

Fig. 2. Effect of dietary a-lipoic acid (LA) on protein expression levels of genes involved in lipid metabolism in intraperitoneal fat (A), hepatopancreas (B) and muscle (C) of grass carp in vivo. Effect of dietary LA on mRNA expression levels of genes involved in lipid metabolism in intraperitoneal fat (D), hepatopancreas (E) and muscle $(F)$ of grass carp in vivo. Values are means, with standard deviations represented by vertical bars, $n 9$. ${ }^{a, b, c}$ Mean values with unlike letters were significantly different between groups, $P<0.05$ (one-factor ANOVA, Duncan's post hoc test). p-AMPK, phosphorylated AMP kinase; t-AMPK, total AMP kinase; ATGL, adipose TAG lipase; LPL, lipoprotein lipase; CPT-1a, carnitine palmitoyltransferase-1a. $\square, 0 \mathrm{mg} / \mathrm{kg}$ LA; $\square, 600 \mathrm{mg} / \mathrm{kg} \mathrm{LA;} \square, 1200 \mathrm{mg} / \mathrm{kg}$ LA.

indicated that $\alpha$-LA could promote lipolysis without loss of body weight and further promote fatty acid $\beta$-oxidation to increase energy supply from lipid catabolism and economise on the protein from energy production to increase protein deposition. In addition, $\alpha$-LA has positive roles in protein synthesis through activating the mTOR pathway.

Mammal studies and human trials indicate that $\alpha$-LA has the capability to reduce body weight, decrease food intake and elevate energy expenditure ${ }^{(34-36)}$. However, in the present study, we revealed a different nutritional pattern in grass carp from mammals. No significant difference in final body weight and the feed conversion ratio was observed among all treatments at doses of 600 and $1200 \mathrm{mg} / \mathrm{kg}(P>0.05)$ (Table 1$)$. The similar studies in aquatic organisms is reported that LA supplementation could cause an increase in the growth of Haliotis discus hannai and T. marginatus following a dose of 800 or $1000 \mathrm{mg} \mathrm{LA} / \mathrm{kg}$ dry food, whereas higher doses (1600 or $3000 \mathrm{mg} \mathrm{LA} / \mathrm{kg}$ dry food) resulted in a decrease in the growth $^{(15,37)}$. This is different from previous result in human and other mammals. While the diets in the present study contained 5\% fat which is at 'normal' levels for grass carp in order to meet nutritional requirements ${ }^{(14)}, \alpha$-LA supplementation at doses of 600 and $1200 \mathrm{mg} / \mathrm{kg}$ significantly decreased the IPF index (Fig. 1(J)) and crude lipid content of the whole body
(Table 1), hepatopancreas (Fig. 1(E)) and muscle (Fig. 1(G)) in the fish $(P<0.05)$. Moreover, $\alpha$-LA remarkably elevated the crude protein content of the whole body and muscle in grass carp $(P<0.05)$ (Fig. 1(L)) although its potential for utilising high-energy diets and for protein-sparing effect is relatively small compared with other aquaculture species, such as salmonids or other carnivorous species ${ }^{(38,39)}$. This may explain why $\alpha$-LA prevents lipid accumulation without negative effect on the body weight of grass carp. The PER and PPV founded in the present study suggest a protein-sparing effect of LA at the dose of $1200 \mathrm{mg} / \mathrm{kg}$ (Fig. 1(M)) rather than $600 \mathrm{mg} / \mathrm{kg}$. In the study of T. marginatus, the protein concentration in the liver was higher in the groups treated with 500 and $1000 \mathrm{mg} / \mathrm{kg}$ compared with the control group and the higher doses group $^{(15)}$. The previous study showed that high-dietary lipid levels could decrease protein utilisation for energy and improve lipid consumption ${ }^{(1)}$. We deduced that $\alpha$-LA supplementation at the dose of $1200 \mathrm{mg} / \mathrm{kg}$ might promote the consumption of lipids and have a protein-sparing effect in grass carp. Fatty acid $\beta$-oxidation is an important source of energy in many animal tissues, including heart, muscle and liver ${ }^{(40)}$. It was further demonstrated that $\alpha$-LA supplementation at the dose of $1200 \mathrm{mg} / \mathrm{kg}$ observably increased NEFA content and decreased TAG content in serum $(P<0.05)$ (Fig. 1(A) and (B)), while it 
(A)

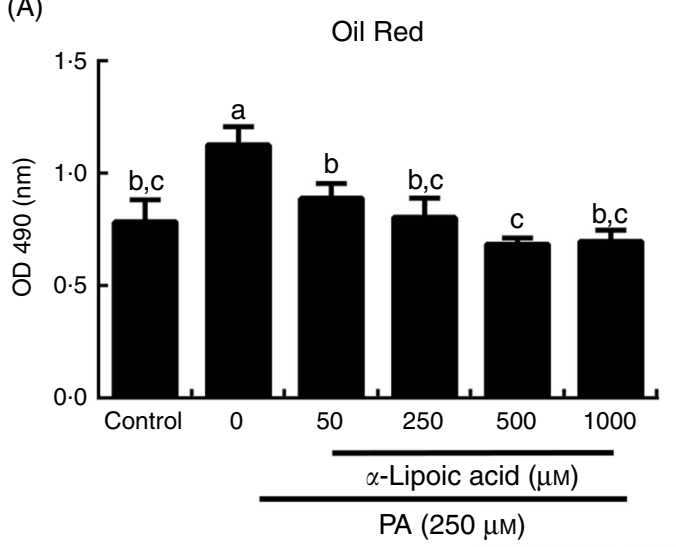

(B)

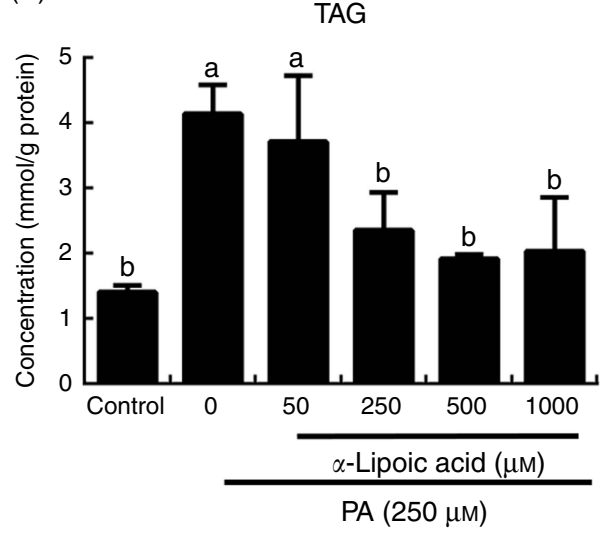

(C)

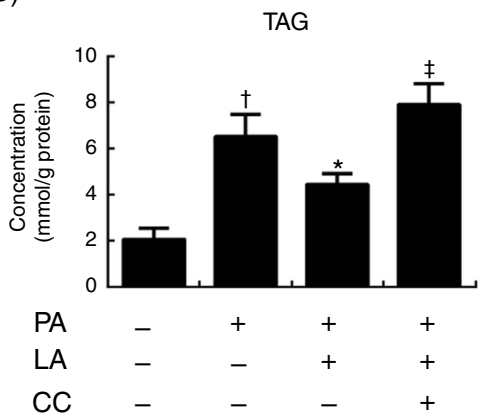

(D)

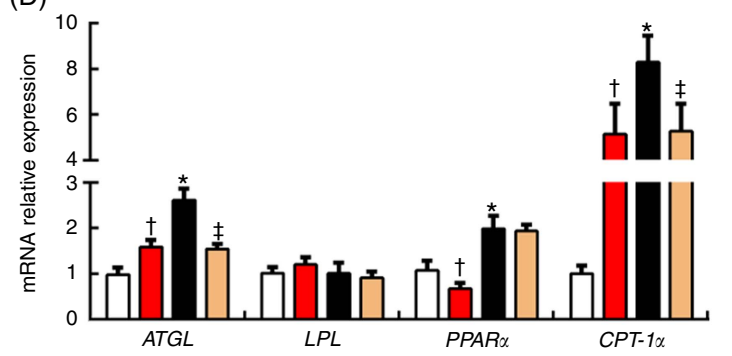

(E)
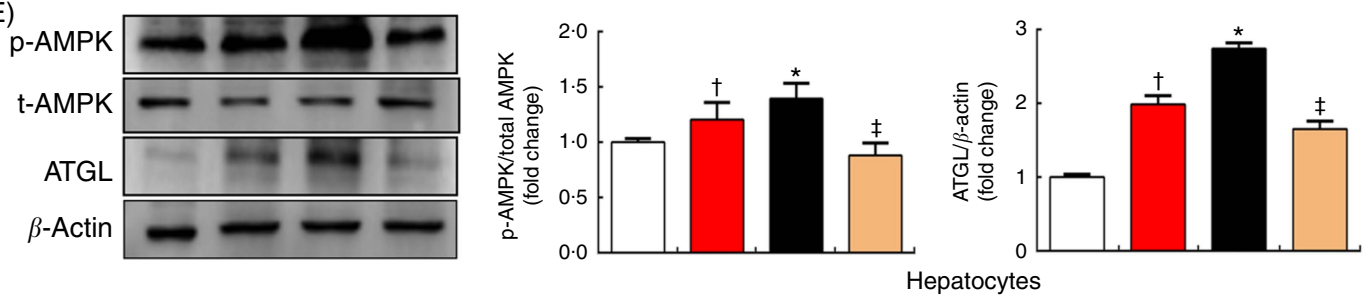

Fig. 3. $a$-Lipoic acid (LA) modulates lipolysis via the AMP kinase (AMPK)-adipose TAG lipase (ATGL) pathway in grass carp hepatocytes. (A) Oil red O staining of hepatocytes upon 24-h $\alpha$-LA treatment $(0,50,250,500$ and $1000 \mu \mathrm{M})$ after $24 \mathrm{~h} 250 \mu \mathrm{m}$ palmitic acid (PA) treatment. Quantification of Oil red O staining was performed by measuring absorbance at $490 \mathrm{~nm}$. (B) TAG content of the hepatocytes upon 24-h $a$-LA treatment $(0,50,250,500$ and $1000 \mu \mathrm{M})$ after $24-\mathrm{h} 250 \mu \mathrm{m}$ PA treatment. (C) TAG content of the hepatocytes in medium with $250 \mu \mathrm{m}$ PA pretreated with compound C (CC; $20 \mu \mathrm{m}$ ) for 30 min before the addition of $a$-LA ( $250 \mu \mathrm{m})$ for $24 \mathrm{~h}$. (D and E) Protein and mRNA expression levels of genes involved in lipid metabolism in the hepatocytes after treatment. The results were obtained from three independent experiments in triplicate. (A and B) Values are means, with standard deviations represented by vertical bars, $n 9$. $^{\mathrm{a}, \mathrm{b}, \mathrm{c}}$ Mean values with unlike letters were significantly different between groups, $P<0.05$ (one-factor ANOVA, Duncan's post hoc test). (C-E) Values are means, with standard deviations represented by vertical bars, $n 9$.

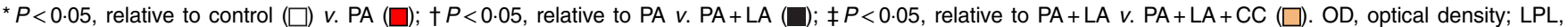
lipoprotein lipase; CPT-1 $a$, carnitine palmitoyltransferase-1 $a$; p-AMPK, phosphorylated AMP kinase; t-AMPK, total AMP kinase.

had no significant effect on the NEFA content of the hepatopancreas and muscle $(P>0 \cdot 05)$ (Fig. 1(F) and $(\mathrm{H})$ ). Therefore, we proposed a hypothesis that the fatty acids transported from blood vessels might be primarily utilised for energy expenditure by $\beta$-oxidation in mitochondria rather than be stored in the hepatopancreas and muscle. As shown in Fig. 2(D) and (E), $\alpha$-LA supplementation at the doses of 600 and $1200 \mathrm{mg} / \mathrm{kg}$ significantly increased the mRNA level of $L P L$ in the muscle and hepatopancreas except for IPF. The main biological function of LPL is to catalyse the hydrolysis of TAG in plasma lipoproteins at the luminal surface of capillaries ${ }^{(41)}$, so $\alpha$-LA might promote the transportation of fatty acids from plasma to tissues.
The present results further showed that $\alpha$-LA supplementation at the doses of 600 and $1200 \mathrm{mg} / \mathrm{kg}$ could up-regulate the transcription of PPAR $\alpha$ and $C P T-1 \alpha$ in the muscle $(P<0.05)$ (Fig. 2(F)), the latter protein being the rate-limiting enzyme for fatty acid $\beta$-oxidation in mitochondria ${ }^{(25)}$. In the previous study, $\alpha$-LA could increase AMPK and acetyl-CoA carboxylase (ACC) phosphorylation, similar to the present study, leading to an increase in palmitate $\beta$-oxidation and decrease in TAG accumulation in $\mathrm{C}_{2} \mathrm{C}_{12}$ myotubes ${ }^{(42)}$. AMPK phosphorylates ACC, which decreases malonyl-CoA levels in cells ${ }^{(43)}$; malonyl Co-A is an inhibitor of CPT- $1 \alpha$ activity $^{(44)}$. Compound C was shown to significantly inhibit CPT- $1 \alpha$ expression in hepatocytes 
(A)

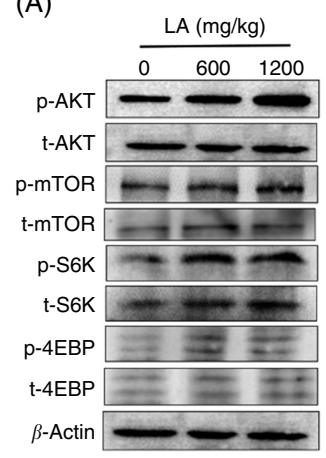

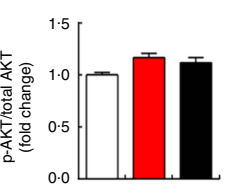

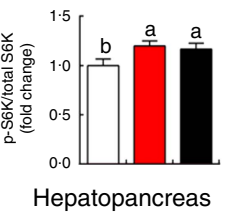

(C)

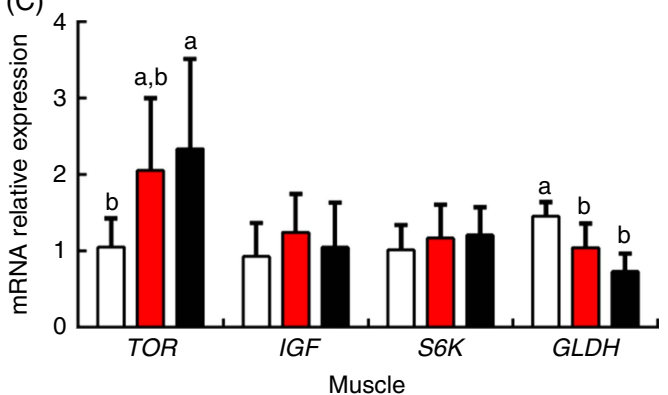

(B)
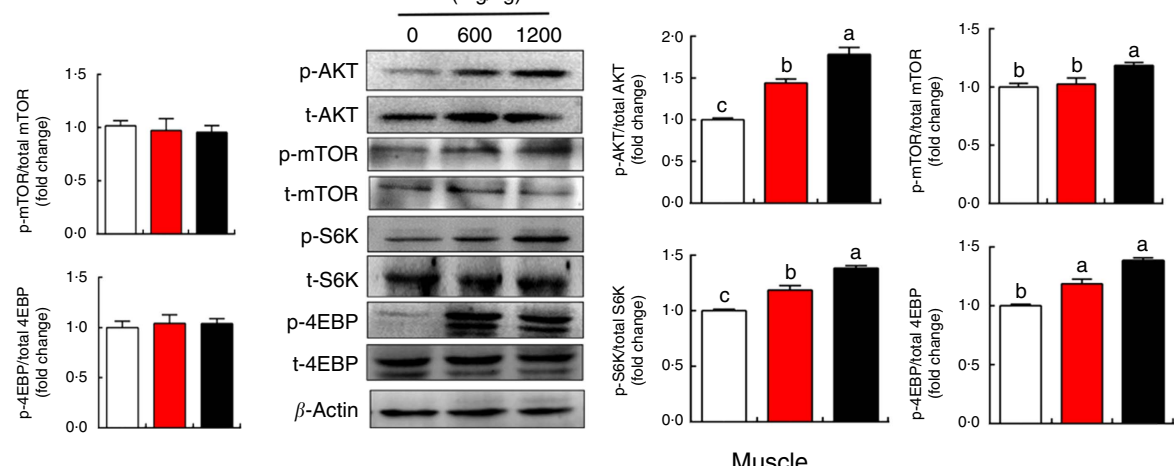

(D)

Fig. 4. Effect of dietary a-lipoic acid (LA) on protein expression of genes involved in protein metabolism in the hepatopancreas (A) and muscle (B) of grass carp in vivo. $(C$ and $D)$ Effect of dietary LA on mRNA expression levels of genes involved in protein metabolism in muscle of grass carp in vivo. Values are means, with standard deviations represented by vertical bars, $n 9$. ${ }^{\text {a,b,c }}$ Mean values with unlike letters were significantly different between groups, $P<0.05$ (one-factor ANOVA, Duncan's post hoc test). p-AMPK, phosphorylated AMP kinase; t-AMPK, total AMP kinase; p-mTOR, phosphorylated mammalian target of rapamycin; t-mTOR, total mammalian target of rapamycin; $p$-S6K, phosphorylated ribosomal protein S6 kinase; t-S6K, total ribosomal protein S6 kinase; $p$-4EBP, phosphorylated eukaryotic initiation factor 4E binding protein; t-4EBP, total eukaryotic initiation factor 4E binding protein; TOR, target of rapamycin; IGF, insulin-like growth factor; S6K, ribosomal protein S6 kinase; GLDH, glutamate dehydrogenase; MyoD, myogenic differentiation antigen; MyoG, myogenin. $\square, 0 \mathrm{mg} / \mathrm{kg}$ LA; $\square, 600 \mathrm{mg} / \mathrm{kg} \mathrm{LA} ; \square, 1200 \mathrm{mg} / \mathrm{kg} \mathrm{LA}$.

of grass carp $(P<0.05)$ (Fig. 3(D)). Therefore, $\alpha$-LA might increase the expression and activity of CPT- $1 \alpha$ via activating phosphorylation of AMPK $\alpha$. Furthermore, $\alpha$-LA significantly decreased the GLDH mRNA level $(P<0.05)$ (Fig. 4(C)), as the key enzyme of amino acid catabolism, reflecting the status of protein catabolism in vivo ${ }^{(45)}$. The present study showed that $\alpha$-LA might promote NEFA $\beta$-oxidation by regulating CPT- $1 \alpha$ through activation of AMPK $\alpha$ phosphorylation to increase energy supply from lipid catabolism, as well as to spare protein from energy production to increase protein deposition.

TAG hydrolysation in lipid droplet is a primary source of $\mathrm{NEFA}^{(34)}$. NEFA released during lipolysis from adipose tissue is transferred using lipoproteins from blood vessels to other tissues, before being transported into mitochondria, ultimately causing the oxidation and reduction in various cofactors that produce $\mathrm{ATP}^{(46)}$. ATGL is a major TAG lipase found in many tissues $^{(9)}$. The present result showed that, while the ATGL protein expression level became significantly increased, $\alpha$-LA dramatically increased the phosphorylation level of AMPK $\alpha$ in the IPF, hepatopancreas and muscle in grass carp $(P<0.05)$ (Fig. 2(A)-(C)). AMPK could integrate hormonal and nutrient signals and transmit these to the hypothalamus. Therefore, AMPK plays an essential role in regulating food intake ${ }^{(47,48)}$. However, phosphorylation of AMPK $\alpha$ activated by $\alpha$-LA supplementation at the doses of 600 and $1200 \mathrm{mg} / \mathrm{kg}$ in the muscle and hepatopancreas had no significant effect on the final body weight and the feed conversion ratio in grass carp
$(P>0.05)$ (Table 1). The result of Chen et al. ${ }^{(49)}$ showed that phosphorylation of AMPK $\alpha$ could increase ATGL protein expression. In the present study, compound C, an inhibitor of AMPK $\alpha$ phosphorylation, markedly inhibited the function of $\alpha$-LA preventing lipid accumulation via elevating ATGL protein expression in grass carp hepatocytes $(P<0.05)$ (Fig. 3 (C)-(E)). The result indicated that $\alpha$-LA might promote ATGL protein expression via activating phosphorylation of AMPK $\alpha$. In addition, dietary $\alpha$-LA at the doses of 600 and $1200 \mathrm{mg} / \mathrm{kg}$ has significantly decreased adipocyte size (Fig. 1(K)) and PPAR $\gamma$ protein expression (Fig. 2(A)) in IPF $(P<0.05)$, indicating that $\alpha$-LA exerts an anti-adipogenic effect in grass carp adipocytes, similar to the results of the study by Cho et al. ${ }^{(50)}$ on 3T3-L1 adipocytes. These results indicated that lipid-lowering function of $\alpha$-LA in grass carp might promote ATGL protein expression via activating phosphorylation of $\mathrm{AMPK} \alpha$ in adipocyte tissue, hepatopancreas and muscle and preventing adipogenesis via mediating PPAR $\gamma$ in adipocytes.

The mTOR pathway plays a key role in protein synthesis and cellular nutrient sensing ${ }^{(51)}$. The results of the present study showed that $\alpha$-LA significantly activated the phosphorylation of the AKT/mTOR/S6K/4E-BP pathway in the muscle of the experimental fish $(P<0.05)$ (Fig. 4(B)). In mammals and fish, dietary $\alpha$-LA could affect the content of free amino acids in the plasma and hippocampal cells ${ }^{(52,53)}$. The previous studies indicated that, while the level of amino acids changes in 
myofibrils, mTOR signalling is activated in mammals and fish ${ }^{(54,55)}$. Therefore, we deduced that $\alpha$-LA might activate mTOR signalling via altering the amino acid content in fish. However, $\alpha$-LA has no effect on MyoD and MyoG, both of which play a vital role in muscle cell proliferation and differentiation $^{(56,57)}$, and it indicated that the promotion of protein synthesis and deposition by $\alpha$-LA was not through affecting muscle cell proliferation and differentiation. These results indicated $\alpha$-LA has positive roles in protein synthesis through activating the mTOR pathway.

In conclusion, the present study demonstrated that $\alpha$-LA could promote lipolysis via activating the AMPK $\alpha$-ATGL pathway in grass carp without loss of body weight and that it could promote fatty acid $\beta$-oxidation by regulating the AMPK $\alpha$-CPT- $1 \alpha$ pathway to increase energy supply from lipid catabolism and spare the protein from energy production to increase protein deposition. Furthermore, $\alpha$-LA has positive roles in protein synthesis through activating the mTOR pathway. So $\alpha$-LA supplemented in diets for grass carp at doses between 600 and $1200 \mathrm{mg} / \mathrm{kg}$ could have a positive effect on lipid and protein metabolism. These results offer new insights into $\alpha$-LA nutrition in vertebrates.

\section{Acknowledgements}

The authors thank Ankang Fisheries Experimental and Demonstration Station of the Northwest Agriculture and Forestry University for the experimental fish.

This work was financially supported by the National Basic Research Program of China (2014CB138603).

X.-c. S., H. J., Z.-y. D. and L.-q. C. conceived and designed the experiments. X.-c. S. and A. J. performed the experiments and contributed to the analysis of the data. X.-c. S., J. S. and J.-j. T. co-wrote the manuscript.

The authors declare that there are no conflicts of interest.

\section{Supplementary material}

For supplementary material/s referred to in this article, please visit https://doi.org/10.1017/S000711451800226X

\section{References}

1. Li X, Jiang Y, Liu W, et al. (2012) Protein-sparing effect of dietary lipid in practical diets for blunt snout bream (Megalobrama amblycephala) fingerlings: effects on digestive and metabolic responses. Fish Physiol Biochem 38, 529-541.

2. Holdsworth M, Ati JE, Bour A, et al. (2013) Developing national obesity policy in middle-income countries: a case study from North Africa. Health Policy Plan 28, 858-870.

3. Kim M-S, Park J-Y, Namkoong C, et al. (2004) Anti-obesity effects of $\alpha$-lipoic acid mediated by suppression of hypothalamic AMP-activated protein kinase. Nature Med 10, 727-733.

4. Stark R, Ashley SE \& Andrews ZB (2013) AMPK and the neuroendocrine regulation of appetite and energy expenditure. Mol Cell Endocrinol 366, 215-223.

5. Ormseth MJ, Swift LL, Fazio S, et al. (2011) Free fatty acids are associated with insulin resistance but not coronary artery atherosclerosis in rheumatoid arthritis. Atherosclerosis 219 , 869-874.

6. Walther TC \& Farese RV Jr (2012) Lipid droplets and cellular lipid metabolism. Ann Rev Biochem 81, 687-714.

7. Hamano Y (2002) Influence of lipoic acid on lipid metabolism and beta-adrenergic response to intravenous or oral administration of clenbuterol in broiler chickens. Reprod Nutr Dev 42, 307-316

8. Jaworski K, Ahmadian M, Duncan RE, et al. (2009) AdPLA ablation increases lipolysis and prevents obesity induced by high-fat feeding or leptin deficiency. Nat Med 15, 159-168.

9. Reid BN, Ables GP, Otlivanchik OA, et al. (2008) Hepatic overexpression of hormone-sensitive lipase and adipose triglyceride lipase promotes fatty acid oxidation, stimulates direct release of free fatty acids, and ameliorates steatosis. J Biol Chem 283, 13087-13099.

10. Kuo YT, Lin TH, Chen WL, et al. (2012) Alpha-lipoic acid induces adipose triglyceride lipase expression and decreases intracellular lipid accumulation in HepG2 cells. Eur J Pharmacol 692, 10-18.

11. Xie R, Li X, Ling Y, et al. (2012) Alpha-lipoic acid pre- and post-treatments provide protection against in vitro ischemiareperfusion injury in cerebral endothelial cells via Akt/mTOR signaling. Brain Res 1482, 81-90.

12. Lv C, Wu C, Zhou YH, et al. (2014) Alpha lipoic acid modulated high glucose-induced rat mesangial cell dysfunction via mTOR/p70S6K/4E-BP1 pathway. Int J Endocrinol 2014, 658589.

13. Wu S, Wang G, Angert ER, et al. (2012) Composition, diversity, and origin of the bacterial community in grass carp intestine. PLOS ONE 7, e30440.

14. Du ZY, Clouet P, Zheng WH, et al. (2006) Biochemical hepatic alterations and body lipid composition in the herbivorous grass carp (Ctenopharyngodon idella) fed high-fat diets. Br J Nutr 95, 905-915.

15. Kütter MT, Monserrat JM, Primel EG, et al. (2012) Effects of dietary $\alpha$-lipoic acid on growth, body composition and antioxidant status in the Plata pompano Trachinotus marginatus (Pisces, Carangidae). Aquaculture 368-369, 29-35.

16. Kütter MT, Romano LA, Ventura-Lima J, et al. (2014) Antioxidant and toxicological effects elicited by alpha-lipoic acid in aquatic organisms. Comp Biochem Physiol C Toxicol Pharmacol 162, 70-76.

17. Glencross BD (2010) Exploring the nutritional demand for essential fatty acids by aquaculture species. Rev Aquacult 1, 71-124.

18. Shi XC, Jin A, Sun J, et al. (2017) $\alpha$-Lipoic acid ameliorates $n$-3 highly-unsaturated fatty acids induced lipid peroxidation via regulating antioxidant defenses in grass carp (Ctenopharyngodon idellus). Fish Shellfish Immunol 67, 359-367.

19. Cunniff P (1995) Official Methods of Analysis of AOAC International, 16th ed. Arlington, VA: AOAC.

20. Zhou Y, Jian S, Hong J, et al. (2017) Pigment epitheliumderived factor improves TNF $\alpha$-induced hepatic steatosis in grass carp (Ctenopharyngodon idella). Dev Comp Immunol 71, $8-17$.

21. Liu P, Ji H, Li C, et al. (2015) Ontogenetic development of adipose tissue in grass carp (Ctenopharyngodon idellus). Fish Physiol Biochem 41, 867-878.

22. Tian JJ, Lei CX, Ji H, et al. (2016) Dietary arachidonic acid has a time-dependent differential impact on adipogenesis modulated via COX and LOX pathways in grass carp Ctenopharyngodon idellus. Lipids 51, 1-14.

23. Osman OS, Selway JL, Kępczyńska MA, et al. (2013) A novel automated image analysis method for accurate adipocyte quantification. Adipocyte 2, 160-164. 
24. Ramírezzacarías JL, Castromuñozledo F \& Kuriharcuch W (1992) Quantitation of adipose conversion and triglycerides by staining intracytoplasmic lipids with oil red O. Histochemistry 97, 493-497.

25. Shi XC, Sun J, Yang Z, et al. (2017) Molecular characterization and nutritional regulation of carnitine palmitoyltransferase (CPT) family in grass carp (Ctenopharyngodon idellus). Comp Biochem Physiol B 203, 11-19.

26. Livak KJ \& Schmittgen TD (2001) Analysis of relative gene expression data using real-time quantitative PCR and the $2^{-\Delta \Delta C_{\mathrm{t}}}$ method. Methods 25, 402-408.

27. Pfaffl MW (2001) A new mathematical model for relative quantification in real-time RT-PCR. Nucleic Acids Res 29, e45.

28. Bian F, Jiang H, Man M, et al. (2017) Dietary gossypol suppressed postprandial TOR signaling and elevated ER stress pathways in turbot (Scophthalmus maximus L.). Am J Physiol Endocrinol Metab 312, E37-E47.

29. Wang JT, Liu YJ, Tian LX, et al. (2005) Effect of dietary lipid level on growth performance, lipid deposition, hepatic lipogenesis in juvenile cobia (Rachycentron canadum). Aquaculture 249, 439-447.

30. Morais S, Bell JG, Robertson DA, et al. (2001) Protein/lipid ratios in extruded diets for Atlantic cod (Gadus morbua L.): effects on growth, feed utilisation, muscle composition and liver histology. Aquaculture 203, 101-119.

31. Boujard T, Gelineau A, Coves D, et al. (2004) Regulation of feed intake, growth, nutrient and energy utilisation in European sea bass (Dicentrarchus labrax) fed high fat diets. Aquaculture 231, 529-545.

32. Guo X, Liang XF, Fang L, et al. (2015) Effects of dietary nonprotein energy source levels on growth performance, body composition and lipid metabolism in herbivorous grass carp (Ctenopharyngodon idella Val.). Aquacult Res 46, 1197-1208.

33. Moura FA, de Andrade KQ, dos Santos JC, et al. (2015) Lipoic acid: its antioxidant and anti-inflammatory role and clinical applications. Curr Top Med Chem 15, 458-483.

34. Kim MS, Park JY, Namkoong C, et al. (2004) Anti-obesity effects of alpha-lipoic acid mediated by suppression of hypothalamic AMP-activated protein kinase. Nat Med 10, 727-733.

35. Song KH, Lee WJ, Koh JM, et al. (2004) $\alpha$-Lipoic acid prevents diabetes mellitus in diabetes-prone obese rats. Biochem Biophys Res Commun 326, 197-202.

36. Prieto-Hontoria PL, Pérez-Matute P, Fernández-Galilea M, et al. (2009) Lipoic acid prevents body weight gain induced by a high fat diet in rats: effects on intestinal sugar transport. J Physiol Biochem 65, 43-50.

37. Zhang W, Chen Q, Mai K, et al. (2010) Effects of dietary $\alpha$-lipoic acid on the growth and antioxidative responses of juvenile abalone Haliotis discus hannai Ino. Aquacult Res $\mathbf{4 1}$, e781-e787.

38. Tian J-J, Lu R-H, Ji H, et al. (2015) Comparative analysis of the hepatopancreas transcriptome of grass carp (Ctenopharyngodon idellus) fed with lard oil and fish oil diets. Gene $\mathbf{5 6 5}$, 192-200.

39. Dabrowski K (1977) Protein requirements of grass carp fry (Ctenopharyngodon idella Val.). Aquaculture 12, 63-73.

40. Tocher DR (2003) Metabolism and functions of lipids and fatty acids in teleost fish. Rev Fish Sci 11, 107-184.
41. Mead JR \& Ramii DP (2002) The pivotal role of lipoprotein lipase in atherosclerosis. Cardiovasc Res 55, 261-269.

42. Chen WL, Kang CH, Wang SG, et al. (2012) $\alpha$-Lipoic acid regulates lipid metabolism through induction of sirtuin 1 (SIRT1) and activation of AMP-activated protein kinase. Diabetologia 55, 1824-1835.

43. Masoodi M, Kuda O, Rossmeisl M, et al. (2015) Lipid signaling in adipose tissue: connecting inflammation and metabolism. Biochim Biophys Acta 1851, 503-518.

44. Borthwick K, Jackson VN, Price NT, et al. (2006) The mitochondrial intermembrane loop region of rat carnitine palmitoyltransferase $1 \mathrm{~A}$ is a major determinant of its malonyl-CoA sensitivity. J Biol Chem 281, 32946.

45. Smutna M \& Vorlova L (2002) Pathobiochemistry of ammonia in the internal environment of fish (review). Acta Vet Brno $\mathbf{7 1}$, 169-181.

46. Holloway GP, Luiken JJFP, Glatz JFC, et al. (2008) Contribution of FAT/CD36 to the regulation of skeletal muscle fatty acid oxidation: an overview. Acta Physiol 194, 293-309.

47. Schneeberger M \& Claret M (2012) Recent insights into the role of hypothalamic AMPK signaling cascade upon metabolic control. Front Neurosci 6, 185.

48. Targonsky ED, Dai F, Koshkin V, et al. (2006) Alpha-lipoic acid regulates AMP-activated protein kinase and inhibits insulin secretion from beta cells. Diabetologia 49, $1587-1598$

49. Chen WL, Chen YL, Chiang YM, et al. (2012) Fenofibrate lowers lipid accumulation in myotubes by modulating the PPAR $\alpha /$ AMPK/FoxO1/ATGL pathway. Biochem Pharmacol 84, 522-531.

50. Cho KJ, Moon HE, Moini H, et al. (2003) Alpha-lipoic acid inhibits adipocyte differentiation by regulating pro-adipogenic transcription factors via mitogen-activated protein kinase pathways. J Biol Chem 278, 34823-34833.

51. Wang X \& Proud CG (2006) The mTOR pathway in the control of protein synthesis. Physiology 21, 362-369.

52. de Freitas RM, De OSF, Saldanha GB, et al. (2011) Lipoic acid alters amino acid neurotransmitters content in rat hippocampus after pilocarpine-induced seizures. Fund Clin Pharmacol 25, 485-492.

53. Terjesen BF, Park K, Tesser MB, et al. (2004) Lipoic acid and ascorbic acid affect plasma free amino acids selectively in the teleost fish pacu (Piaractus mesopotamicus). J Nutr 134, 2930-2934.

54. Kimball SR \& Jefferson LS (2006) Signaling pathways and molecular mechanisms through which branched-chain amino acids mediate translational control of protein synthesis. J Nutr 136, 227S-231S.

55. Lansard M, Panserat S, Plagnes-Juan E, et al. (2011) L-Leucine, L-methionine, and L-lysine are involved in the regulation of intermediary metabolism-related gene expression in rainbow trout hepatocytes. J Nutr 141, 75-80.

56. Rudnicki MA, Schnegelsberg PNJ, Stead RH, et al. (1993) MyoD or Myf-5 is required for the formation of skeletal muscle. Cell 75, 1351-1359.

57. Wright WE, Sassoon DA \& Lin VK (1989) MYOG, a factor regulating myogenesis, has a domain homologous to Myo D. Cell 56, 607-617. 